\title{
ANALISIS KORELASI KANONIKAL PADA KOMPONEN DUA SISI NERACA PERUSAHAAN PERBANKAN GO PUBLIK DI INDONESIA (Periode 2005-2011)
}

\author{
Tien Sukaesih \\ Dosen tetap pada Jurusan IImu Akuntansi FE Universitas Jenderal Soedirman
}

\begin{abstract}
Abstrak
Penggunaan statistik sudah sering dijumpai pada hasil-hasil penelitian bidang eksakta maupun sosial, hal tersebut diantaranya diuraikan pada artikel-artikel hasil penelitian berbagai jurnal, baik pada penelitian yang berorientasi ingin mendeskripsikan masalah atau variabel penelitian, untuk tujuan eksplorasi maupun yang bertujuan untuk pengujian hipotesis penelitian. Kajian ini membahas tentang bagaimana statistika kanonik dapat diterapkan dengan menganalisis tujuan laporan keuangan, karakteristik kualitatif laporan keuangan, unsur-unsur (elemen) laporan keuangan, pengakuan atas unsur-unsur laporan keuangan, pengukuran atas unsur-unsur laporan keuangan; dan konsep modal dan pemeliharaan modal. Hasil kajian ini menunjukkan bahwa 20 neraca bank dengan menggunakan metode statistik analisis kanonikal memberikan kesimpulan bahwa terdapat hubungan yang bermakna di antara kedua sisi neraca. Hal ini terlihat dari hubungan yang kuat dan searah antara komponen piutang dengan hutang, Ekuitas dengan kas dan surat berharga, dan Ekuitas dengan aktiva tak lancar. Hal ini sekaligus membuktikan hipotesis, yang ditunjukkan oleh pola hubungan yang berhasil diidentifikasi di antaranya hubungan searah positif dan negatif atau perubahan proporsional diantara komponen yang berhubungan.
\end{abstract}

Kata Kunci: kanonikal, neraca, ekuitas, kas, piutang, hutang

\section{PENDAHULUAN}

Kemajuan di bidang ekonomi dapat dicapai berkat adanya kebijakan makro ekonomi yang mendukung, juga tidak lepas dari kemampuan pengelolaan perusahaan secara mikro yang memadai, dimana sistem perdagangan dunia semakin bebas (Globalization), pelaku usaha di Indonesia tidak dapat lagi terus-menerus mengandalkan perlindungan pemerintah (Protection Political Governance). Karena itu, orientasi mendapat konsesi, proteksi atau subsidi harus diubah menjadi orientasi meningkatkan kemampuan pengelolaan perusahaan (Wallace dan Zinkin, 2005).

Pada tahap ini studi empiris mengenai kemampuan pengelolaan perusahaan menjadi sangat penting, studi tersebut dapat memberikan pemahaman lebih baik tentang kondisi pengelolaan perusahaan yang selama ini dilaksanakan, dengan demikian dapat diperoleh masukan mengenai bagaimana meningkatkannya dimasa datang. Terkait dengan kepentingan perusahaan untuk menyelenggarakan good governance, maka kedudukan dewan komisaris dan dewan direksi menjadi sangat penting. Dewan Komisaris adalah sekelompok individual yang dipilih dengan tanggung jawab utamanya adalah tindakan atas kepentingan pemilik dengan secara formal memonitor dan mengendalikan eksekutif puncak korporat. Selanjutnya Dewan Komisaris membentuk Dewan Direksi (manajemen). Fungsi direksi adalah fungsi pengendalian manajemen yang secara sistematis menetapkan performa standar dengan perencanaan sasaran guna mendesain informasi umpan balik bagi pemegang saham, membandingkan prestasi kerja dengan standar yang telah ditetapkan lebih dulu, dan apakah terhadap penyimpangan telah diambil tindakan untuk memastikan sumber daya perusahaan 
dimanfaatkan secara efektif guna mencapai tujuan perusahaan (Wallace dan Zinkin, 2005).

\section{KERANGKA PEMIKIRAN}

Unsur-unsur laporan keuangan berikut ini berkaitan langsung dengan pengukuran posisi keuangan:

a. Aktiva, sumber daya yang dikuasai oleh perusahaan sebagai akibat dari peristiwa masa lalu dan dari mana manfaat ekonomi di masa depan diharapkan dapat diperoleh perusahaan;

b. Kewajiban, utang perusahaan saat ini yang timbul dari peristiwa masa lalu, yang penyelesaiannya diharapkan mengakibatkan arus keluar dari manfaat ekonomi perusahaan.

c. Ekuitas, aktiva dikurangi dengan kewajiban (umumnya dikenal sebagai dana pemegang saham).

Unsur-unsur yang berkaitan langsung dengan pengukuran kinerja sebagai berikut:

a. Penghasilan atau pendapatan (income), kenaikan manfaat ekonomi dalam bentuk pemasukan atau penambahan aktiva atau penurunan kewajiban yang mengakibatkan kenaikan ekuitas (yang tidak berasal dari kontribusi pemilik/penanam modal). Penghasilan meliputi pendapatan dan keuntungan.

b. Beban (expense), penurunan manfaat ekonomi dalam bentuk arus keluar atau berkurangnya aktiva atau terjadinya kewajiban yang mengakibatkan penurunan ekuitas (selain penurunan karena distribusi kepada pemilik/penanam modal).

Suatu unsur laporan keuangan (aktiva, kewajiban, ekuitas, penghasilan, dan beban) seharusnya diakui dalam laporan keuangan apabila:

a) Besar kemungkinan (probable) bahwa manfaat ekonomi yang berkaitan dengan pos tersebut akan mengalir ke atau dari dalam perusahaan; b) Pos tersebut mempunyai biaya atau nilai yang dapat diukur dengan andal.

Dasar-dasar berikut digunakan dalam derajat dan kombinasi yang berbeda untuk mengukur unsur-unsur laporan keuangan:

a) Biaya historis

b) Biaya kini

c) Nilai realisasi (penyelesaian)

d) Nilai sekarang atau kini (present value)

Konsep modal dan pemeliharaan modal mencakup:

a) Modal keuangan. Modal sama dengan aktiva bersih atau ekuitas; didefinisikan dalam satuan moneter nominal. Laba merupakan kenaikan dalam modal nominal uang sepanjang periode.

b) Modal fisik. Modal dianggap sebagai kemampuan usaha; didefinisikan dalam kapasitas produktif. Laba merupakan kenaikan kapasitas produktif sepanjang periode.

Salah satu aspek pengelolaan perusahaan yang penting untuk ditelaah adalah aspek manajemen keuangan, dalam penelitian aspek manajemen keuangan perusahaan di Indonesia terutama perusahaan perbankan, yang akan dikaji adalah apakah ada hubungan yang saling terkait antara masing-masing pos neraca baik sisi kiri dengan kanan maupun sebaliknya. Berdasarkan hal tersebut, hubungan yang terjadi di neraca perusahaan perbankan, terutama ditujukan pada fenomena hubungan di dalam neraca perusahaan perbankan di Indonesia menarik untuk diteliti karena akan bermanfaat bukan saja bagi pengembangan ilmu pengetahuan khususnya ilmu akuntansi keuangan, tetapi juga akan bermanfaat bagi perusahaan dalam menginventarisir komponen manajemen keuangan pada neraca yang dijadikan perhatian penelitian ini, yaitu Kas, Piutang, Aktiva Tak Lancar, Hutang Usaha, Pinjaman Jangka Panjang, dan Ekuitas. Tujuan dari penelitian ini adalah untuk: (1) Mengevaluasi 
pelaksanaan fungsi manajemen keuangan yang dilakukan oleh perusahaan perbankan di Indonesia, terutama mengenai aspek manajemen modal kerjanya; (2) Mengidentifikasi seberapa erat hubungan antara komponen di dalam kedua sisi neraca perusahaan; (3) Menjelaskan alasan terjadinya hubungan tersebut, untuk memberikan pemahaman makro tentang manajemen keuangan di perusahaan perbankan di Indonesia; (4) Mengidentifikasi fungsi persamaan (kombinasi) linear yang menjelaskan hubungan yang terjadi antara komponen di kedua sisi neraca. Komponen Manajemen Keuangan pada neraca yang dijadikan perhatian penelitian ini adalah Kas, Piutang, Aktiva Tak Lancar, Hutang Usaha, Pinjaman Jangka Panjang, dan Ekuitas. Keterkaitan antar komponen di sisi kiri (komponen 1 sampai 3) dan komponen di sisi kanan (komponen 4 sampai 6) akan diidentifikasi dan dijelaskan lebih lanjut.

\section{KAJIAN PUSTAKA}

Standar Akuntansi seharusnya disusun berdasarkan suatu kerangka dasar atau prinsipprinsip dasar yang koheren dan dapat diterima. Komite Standar Akuntansi Internasional (International Accounting Standards Committee/IASC); sekarang disebut Badan Standar Akuntansi Internasional (International Accounting Standards Board/IASB) menerbitkan Kerangka Dasar Penyusunan dan Penyajian Laporan Keuangan (Framework for the Preparation and Presentation of Financial
Statements) pada tahun 1989 dan IASB menerapkannya pada tahun 2001. Kerangka dasar IASB ini (1) memperkenalkan konsepkonsep menyangkut penyusunan dan penyajian laporan keuangan; (2) menuntun para penyusun standar dalam mengembangkan standar akuntansi; dan (3) membantu para penyusun, auditor dan pengguna dalam menginterpretasikan Standar Akuntansi Internasional (International Accounting Standards/IAS) dan membahas masalah-masalah yang belum dibahas oleh IAS.

Kerangka dasar bukanlah sebuah standar, tetapi digunakan secara utuh oleh IASB dan oleh komite interpretasi IASB yaitu Komite Interpretasi Pelaporan Keuangan Internasional (International Financial Reporting Interpretations Committee/IFRIC).

Kerangka dasar ini membahas (1) tujuan laporan keuangan; (2) karakteristik kualitatif laporan keuangan; (3) unsur-unsur (elemen) laporan keuangan, (4) pengakuan atas unsurunsur laporan keuangan, (5) pengukuran atas unsur-unsur laporan keuangan; dan (6) konsep modal dan pemeliharaan modal.

Tujuan laporan keuangan adalah untuk menyediakan informasi tentang posisi keuangan (neraca), kineija (laporan laba rugi), dan perubahan posisi keuangan (laporan arus kas) suatu perusahaan; informasi ini harusnya bermanfaat bagi para pengguna yang bermaksud mengambil keputusan ekonomi.

Berikut ini adalah asumsi-asumsi dasar laporan keuangan (lihat Tabel 3 halaman berikutnya): 
Tabel 3

Transparansi dalam Laporan Keuangan Berdasarkan Kerangka Dasar IASB

\section{Tujuan Laporan Keuangan}

Untuk menyediakan penyajian yang wajar atas:

1. Posisi Keuangan

2. Kinerja Keuangan

3. Arus Kas

\section{Transaksi dan Penyajian Wajar}

1. Penyajian wajar dicapai melalui penyediaan informasi yang berguna (pengukapan penuh) yang menjamin transparansi

2. Penyajian wajar dengan Transparansi

Tujuan Sekunder Laporan Keuangan

Untuk menjamin transparansi melalui penyajian yang wajar atas informmasi yang berguna (pengungkapan penuh) untuk tujuan pengambilan keputusan.

1. Relevan

\section{Karakteristik Informasi Yang Berguna}

a. Hakikat

b. Materialitas

2. Keandalan
a. Penyajian yang jujur
c. Netralitas
d. Pertimbangan sehat
e. Kelengkapan

b. Substansi mengungguli bentuk

3. Dapat dibandingkan

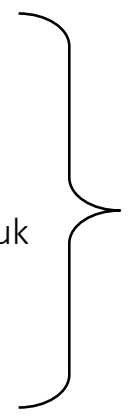

\section{Kendala}

Tepat Waktu

Manfaat VS Biaya

Keseimbangan Karakter

Kualitatif

\section{Dapat dipahami \\ ASUMSI DASAR}

Dasar akrual Kelangsungan Usaha

Keseimbangan Karakter Kualitatif

Neraca perusahaan mencerminkan posisi aktiva dan kewajiban-ekuitas pada saat tertentu, nilai buku jumlah aktiva harus selalu sama dengan nilai buku jumlah kewajiban-ekuitasnya. Aktiva biasa dibedakan menjadi aktiva lancar (Kas dan surat berharga, piutang, persediaan) dan aktiva tak-lancar, sementara itu kewajibanekuitas terdiri atas kewajiban lancar (hutang usaha dan pinjaman jangka pendek), kewajiban jangka penjang dan ekuitas. Selanjunya Neraca bertujuan untuk melaporkan posisi keuangan (jumlah asset, kewajiban, dan ekuitas pemegang saham) dari suatu entitas akuntansi pada satu titik waktu tertentu (Libby, Libby, dan Short, 2007).
Informasi komposisi komponen aktiva dan kewajiban-ekuitas merupakan bahan penting untuk memahami pelaksanaan manajemen keuangan perusahaan. Banyak literature yang menjelaskan teori keuangan modern bahwa dalam penentuan kompisisi komponen aktiva dan kewajiban-ekuitas dilakukan secara tidak terikat, ketidak-terikatan antara pengambilan keputusan investasi dan pembiayaan merupakan temuan penting dari studi manajemen keuangan yang dilakukan oleh Modigliani \& Miller (1958). Namun demikian pada kenyataannya studi-studi investasi pembiayaan tidak mampu membuktikan adanya ketidak-terikatan antara komposisi komponen sisi aktiva dan kewajibanekuitas. 
Berdasarkan kenyataan tersebut, maka perkembangan studi-studi berikutnya justru diarahkan untuk mengidentifikasi dan menjelaskan terjadinya keterkaitan antara komponen di dalam kedua sisi neraca. Studi semacam ini tidak menggunakan asumsi ketidakterikatan antara keputusan investasi dan pembiayaan dengan alasan bahwa apabila keputusan tersebut saling tidak terikat, keputusan simultan dalam periode relatif singkat tetap harus dilakukan karena setiap keputusan investasi harus diikuti dengan keputusan pembiayaan atau sebaliknya. Sejalan dengan arah perkembangan tersebut, maka studi inipun tidak memakai asumsi ketidak-terikatan antara keputusan investasi dan pembiayaan yang ditawarkan oleh Modigliani dan Miller.

(1) Dasar akrual. Pengaruh transaksi dan peristiwa'lain diakui pada saat kejadian (bukan saat kas mengalir/diterima atau dibayar). Pengaruh ini dicatat dan dilaporkan dalam laporan keuangan pada periode yang bersangkutan.

(2) Kelangsungan usaha (going concern). Diasumsikan bahwa perusahaan atau entitas akan melanjutkan usahanya di masa depan.

Karakteristik kualitatif adalah berbagai atribut yang membuat informasi dalam laporan keuangan bermanfaat bagi para pengguna:

(1) Relevan, informasi yang relevan memengaruhi keputusan ekonomi yang diambil pengguna, membantu mereka untuk mengevaluasi peristiwa masa lalu, masa kini, dan masa depan atau menegaskan atau mengoreksi evaluasi masa lalu. Relevansi suatu informasi dipengaruhi oleh hakikat dan materialitasnya.

(2) Keandalan, informasi yang andal berarti bebas dari kesalahan material dan pengertian yang menyesatkan dan dapat diandalkan pemakainya sebagai penyajian yang tulus (jujur) atas yang seharusnya dapat disajikan atau yang secara wajar diharapkan dapat disajikan. Faktor-faktor berikut berpengaruh terhadap keandalan: (a) penyajian yang jujur (faithful representation); (b) substansi mengungguli bentuk (substance over form); (c) netralitas (neutrality); (d) pertimbangan sehat (prudence); (e) kelengkapan (completeness).

(3) Dapat dibandingkan, informasi seharusnya disajikan secara konsisten dari satu periode ke periode berikutnya dan secara konsisten antar perusahaan (entitas) sehingga memungkinkan pengguna untuk melakukan perbandingan yang signifikan.

(4) Dapat dipahami, informasi seharusnya dapat dipahami dengan mudah oleh pengguna yang memiliki pengetahuan dasar tentang bisnis, aktivitas ekonomi, dan akuntansi, dan memiliki kemauan untuk mempelajari informasi dengan ketekunan yang wajar.

Studi ini menggunakan pendekatan mikro dengan memakai model keterkaitan antara komponen di sisi aktiva dengan komponen di sisi kewajiban-ekuitas yang dikembangkan oleh Stowe (1980). Kriteria yang dipakai dalam model ini diantaranya adalah :

(1) Terdapat hubungan yang negatif antara ke dua komponen aktiva dan pasiva, artinya bila terjadi penambahan disisi aktiva maka akan terjadi pengurangan di sisi pasivanya baik secara proporsional atau relatif.

(2) Terdapat hubungan (korelasi) positif antara aktiva dengan pasiva, artinya bila terjadi penambahan atau pengurangan di sisi aktiva maka akan terjadi penambahan atau pengurangan di sisi pasiva baik secara proporsional maupun relatif.

(3) Perubahan proporsional dan relatif secara positif maupun negatif dapat juga berlaku didalam masing-masing komponen pasiva maupun aktiva.

Di samping itu untuk mengambil suatu kesimpulan yang bisa digunakan secara universal, penulis juga menilai seberapa jauh korelasi antar komponen ini berlaku untuk berbagai hubungan 
antar komponen dan seberapa jauh simpangan atau deviasi yang terjadi dan dapat diterima.

\section{METODE PENELITIAN}

Obyek dalam penelitian ini adalah Laporan Keuangan atas Perusahaan Perbankan yang telah Go Publik untuk tahun buku 2005/2006 dan dari 25 perusahaan perbankan yang telah go publik, penulis mengambil sampel sebanyak 20 buah Laporan Keuangan perusahaan perbankan tersebut. Penarikan sampel dilakukan dengan memilah aset total setiap bank menjadi beberapa kelompok, yaitu kelompok bank yang beraset 5 triliun, 1 triliun sampai 5 triliun, 500 milyar sampai 1 triliun dan aset sampai dengan 500 milyar.

Rincian jumlah sampling dari masing-masing kelompok bank tersebut dapat diringkaskan sebagai berikut:

$\begin{array}{ll}\text { - Aset di atas } 5 \text { triliun } & 9 \text { Bank dari } 16 \text { Bank } \\ \text { - Aset } 1 \text { triliun s/d } 5 \text { triliun } & 9 \text { Bank dari } 47 \text { Bank } \\ \text { - Aset } 500 \text { milyar s/d } 1 \text { triliun } & 1 \text { Bank dari } 38 \text { Bank } \\ \text { - Aset s/d } 500 \text { milyar } & 1 \text { Bank dari } 119 \text { Bank }\end{array}$

Data dikumpulkan dengan teknik komunikasi tidak langsung yaitu melalui telaah kepustakaan dan pengumpulan informasi yang relevan. Data yang dikumpulkan berupa data sekunder yang bersumber dari perusahaan melalui Indonesian Capital Market Directory (ICMD) yang dikeluarkan oleh Institute for Economic and Financial Research (IEFR).

Teknik pengolahan data dilakukan dengan cara mengumpulkan data yang relevan, kemudian diedit dan dibuatkan daftar tabel yang erat hubungannya dengan masalah yang sedang dibahas, pembuatan daftar tabel dilakukan dengan bantuan komputer dan menggunakan Software SPSS yang dikembangkan melalui Analisis Korelasi Kanonikal untuk mempercepat dan memudahkan perhitungannya.

Analisis korelasi kanonikal digunakan untuk menganalisis bentuk dari interaksi antar dua sisi neraca dan memfokuskan diri pada korelasi antara kombinasi linear variabel di satu sisi dengan kombinasi linier di sisi variabel yang lain.

\section{HASIL \& PEMBAHASAN}

Terdapat 20 neraca yang memenuhi syarat sebagai data penelitian, terdapat simpangan struktur neraca yang besar, mengingat mayoritas perusahaan sampel merupakan perusahaan perbankan yang relatif belum lama mencatatkan sahamnya di Bursa Efek Jakarta.

Berdasarkan hasil penelitian diketahui ratarata proporsi Komponen Ekuitas mencapai 0.101, bahkan terdapat 10 perusahaan atau setengah dari sampel mempunyai Komponen Ekuitas kurang dari 0.100 dan separuh lainnya mempunyai proporsi lebih dari 0.100. Sementara itu rata-rata proporsi komponen Hutang Usaha Perusahaan mencapai 0.803 dimana 4 diantaranya bahkan melebihi 0.900 .

Walaupun rata-rata proporsi komponen hutang usaha lebih besar dari pada rata-rata proporsi hutang jangka panjang terdapat 7 perusahaan yang proporsi hutang usahanya di bawah 0.800 dan 11 perusahaan mempunyai proporsi hutang jangka panjangnya di bawah 0.100. Besarnya rata-rata proporsi komponen ekuitas disisi kanan diimbangi dengan rata-rata proporsi aktiva tak lancar di sisi kiri yang besarnya 0.057. Dan terdapat 7 perusahaan yang proporsi aktiva tidak lancarnya di atas 0.050, pengalokasian aset pada aktiva lancar hampir merata dengan rata-rata proporsi komponen kas dan surat berharga serta piutang masing-masing 0,206 dan 0.738. Dalam hal ini hanya satu perusahaan yang menempatkan sepertiga asetnya pada aktiva tidak lancar dan hampir semua perusahaan menempatkan separuh lebih asetnya pada proporsi piutang.

Berikut ini disajikan korelasi linear antar komponen di sisi kiri neraca, dan disisi kanan neraca serta korelasi linier di sisi kiri dan komponen di sisi kanan neraca sebagai berikut : 
Tabel 1

Korelasi antar Komponen di Sisi Kiri Neraca

\begin{tabular}{lrrr}
\hline Komponen & Kas dan SB & Piutang & $\begin{array}{l}\text { Akt tak } \\
\text { lancar }\end{array}$ \\
\hline Kas dan SB & 1.000 & -0.713 & -0.240 \\
\hline Piutang & -0.713 & 1.000 & -0.503 \\
\hline Akt tak lancar & -0.240 & -0.503 & 1.000 \\
\hline
\end{tabular}

Sumber: Hasil perhitungan menggunakan SPSS, Januari, 2012

Tabel 2

Korelasi antar komponen di sisi kanan neraca

\begin{tabular}{lrrr}
\hline \multicolumn{1}{c}{ Komponen } & \multicolumn{1}{c}{$\begin{array}{c}\text { Hutang } \\
\text { Usaha }\end{array}$} & $\begin{array}{c}\text { Kew. J. } \\
\text { Panjang }\end{array}$ & Ekuitas \\
\hline Hutang Usaha & 1.000 & -0.955 & -0.294 \\
\hline Kw.J. Panjang & -0.955 & 1.000 & -0.001 \\
\hline Ekuitas & -0.240 & -0.503 & 1.000 \\
\hline
\end{tabular}

Sumber: Hasil perhitungan menggunakan SPSS, 2012

Tabel 3

Korelasi antar komponen di sisi kanan dan di sisi kiri neraca

\begin{tabular}{lcrr}
\hline Komponen & $\begin{array}{c}\text { Hutang } \\
\text { Usaha }\end{array}$ & $\begin{array}{l}\text { Kew. J. } \\
\text { Panjang }\end{array}$ & Ekuitas \\
\hline Kas dan SB & $-0,137$ & 0.133 & 0.020 \\
\hline Piutang & 0.138 & 0.109 & -0.106 \\
\hline
\end{tabular}

\begin{tabular}{llll}
\hline Akt tak lancer & -0.029 & -0.209 & 0.194 \\
\hline
\end{tabular}

Sumber: Hasil perhitungan menggunakan SPSS, Januari, 2007

Korelasi atau hubungan antar komponen yang diuraikan di atas memberikan arti tentang hubungan perubahan di masing-masing komponen dan pengaruhnya diantara komponen yang mempunyai korelasi, baik searah maupun berlawanan arah. Contohnya dapat dijelaskan antara lain bila Piutang bertambah, maka ada kemungkinan Hutang Usaha juga bertambah sebagai akibat korelasi searah, demikian juga seandainya Piutang bertambah mungkin Aktiva berkurang sebagaimana hubungan berlawanan arah di kedua komponen tersebut.

Korelasi linier di atas mempunyai arti yang terbatas sebab hanya menunjukkan hubungan antar satu komponen dengan komponen lainnya, dan oleh karena hubungan antara satu komponen dengan komponen lainnya ditentukan oleh seluruh komponen terkait lainnya maka digunakan analisa korelasi kanonikal.

Hasil korelasi kanonikal dapat dilihat pada tabel berikut :

Tabel 4

Hasil Korelasi Kanonikal

\begin{tabular}{ccccccc}
\hline Fungsi & Kor-kan & Kor-kan koreksi & Estimasi Standars deviasi & Kuadrat Kor-kan & F Statistik & Proba-bility \\
\hline 1 & 0.593 & 0.481 & 0.149 & 0.352 & 0.864 & 0.566 \\
\hline 2 & 0.249 & 0.083 & 0.215 & 0.062 & 0.244 & 0.911 \\
\hline 3 & 0.015 & 0.000 & 0.229 & 0.000 & 0.004 & 0.953 \\
\hline
\end{tabular}

Sumber: Hasil perhitungan dengan menggunakan SPSS, 2012

Untuk mengetahui korelasi antara variabel asli dengan fungsi variabel kanonikalnya dan korelasi antara variabel asli dengan fungsi variabel kanonikal lawannya dapat dilihat pada table berikut :

Tabel 5

Korelasi antara Variabel Asli dengan Fungsi Variabel Kanonikal

\begin{tabular}{lccc}
\hline \multirow{2}{*}{ Komponen } & \multicolumn{4}{c}{ Fungsi Variabel Kanonikal } \\
\cline { 2 - 4 } & $\mathbf{1}$ & $\mathbf{2}$ & $\mathbf{3}$ \\
\hline Kas dan SB & 0.063 & -0.968 & -0.247 \\
\hline
\end{tabular}

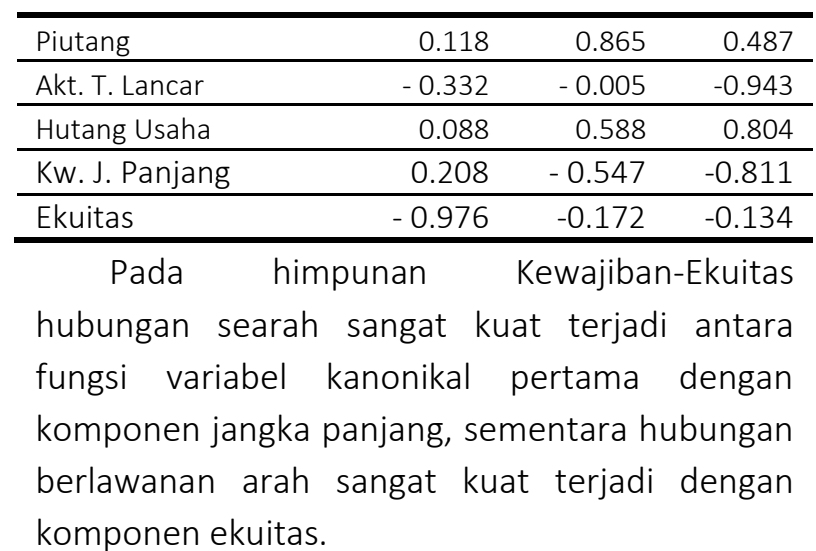

Tabel 6 
Korelasi antara Variabel Asli dengan Fungsi Variabel Kanonikal Lawannya

\begin{tabular}{lrrr}
\hline \multirow{2}{*}{ Komponen } & \multicolumn{3}{c}{ Fungsi Variabel Kanonikal } \\
\cline { 2 - 4 } & \multicolumn{1}{c}{$\mathbf{1}$} & \multicolumn{1}{c}{$\mathbf{3}$} \\
\hline Kas dan SB & 0.021 & -0.241 & -0.004 \\
\hline Piutang & 0.070 & 0.215 & 0.007 \\
\hline Akt. T. Lancar & -0.197 & -0.001 & -0.014 \\
\hline Hutang Usaha & 0.052 & 0.146 & 0.012 \\
\hline Kw. J. Panjang & 0.123 & -0.136 & -0.012 \\
\hline Ekuitas & -0.580 & -0.043 & -0.002 \\
\hline
\end{tabular}

Berdasarkan uraian di atas, keterkaitan antara struktur aktiva dan kewajiban-ekuitas yang menjadi perhatian penelitian dapat dikatakan terbukti serta mampu membuktikan hipotesis, walaupun tidak berhasil menjelaskan seluruh pola hubungan antar komponen yang secara teoretis mungkin terjadi.

Penelitian ini berhasil menemukan beberapa pola keterkaitan yang secara nyata terjadi antara lain :

1. Terdapat korelasi negatif diantara masingmasing komponen di sisi Aktiva maupun Pasiva, korelasi ini menunjukkan bahwa bila salah satu komponen berubah positif maka komponen yang berkorelasi dengan komponen tersebut akan berubah negatif.

2. Terdapat korelasi yang positif antara komponen di sisi kiri neraca dengan komponen di sisi kanan neraca, korelasi ini menjelaskan adanya hubungan yang erat sejajar dalam perubahan masing-masing komponen berkorelasi. Artinya bila komponen Piutang berubah, maka komponen Hutang Usaha akan berubah proporsional dengan perubahan piutang.

3. Terdapat hubungan searah (positif) yang kuat antara komponen Piutang dengan Hutang Usaha, Kas dan Surat Berharga dengan Ekuitas dan Kewajiban Jangka Panjang, Aktiva tak Lancar dengan Ekuitas, sementara hubungan komponen lainnya bersifat berlawanan arah (negatif).

4. Perusahaan sampel cenderung menyesuaikan struktur jatuh tempo antara aktiva dengan kewajiban-ekuitas, pola hubungan dimaksud terlihat kuat pada komponen piutang dengan hutang usaha dan kurang kuat pada komponen piutang dengan kewajiban jangka panjang, di lain pihak terdapat juga hubungan yang sangat kuat antara komponen aktiva tak lancar dengan ekuitasnya, hal ini terjadi karena pembelian aktiva tak lancar dibiayai dengan modal perusahaan.

\section{KESIMPULAN}

Berdasarkan hasil kajian atas 20 neraca bank dengan menggunakan metode statistik analisis kanonikal dapat disimpulkan bahwa terdapat hubungan yang signifikan atau berkaitan secara nyata di antara kedua sisi neraca. Hal ini terlihat dari hubungan kuat searah antara komponen piutang dengan hutang $(0,138)$, Ekuitas dengan kas dan surat berharga $(0,020)$, dan Ekuitas dengan aktiva tak lancar $(0,194)$. Hal ini sekaligus membuktikan hipotesa. Pola hubungan yang berhasil diidentifikasi diantaranya hubungan searah positif dan negatif atau perubahan proporsional diantara komponen yang berhubungan.

\section{DAFTAR PUSTAKA}

Ball, R. and P. Brown, 1968. An Empirical Evaluation of Accounting Income Numbers. Journal of Accounting Research (Autum): 589-609.

Brandon, Charles H \& Ralph E. Drtina., 1997. Management accounting; strategy and control. Canada: Mc.Graw-Hill Companies, Inc.

Buffa, Elwood S and Rakesh K. Sarin, 1999. Manajemen operasi dan produksi Modern (Terjemahan: Agus Maulana) Edisi Kedelapan. Jakarta: Binarupa Aksara. 
Firdausyi, Carunia Mulya, Perdagangan bebas dalam APEC 2020: Masalah dan hambatan bagi Indonesia. Kelola: Gajah Mada University Business Review No.11/VI/1996. pp.93-109.

Ghartey JB, 1987. Crisis, Accountability and Development in Third World. London

Hamel, Garry \& C.K. Prahalad. 1994. Competing for the future. Boston: Harvard Business School Press.

Hill, Terry., 2000. The essence of operations management (terjemahan: Chandrawati dan Dwi Prabantini) First Edition. Yogyakarta: Andi and Simon and Schuster (Asia) Ltd.

Horngren, Charles T., George Foster, Srikant M. Datar. 2000. Cost accounting: a managerial emphasis, $10^{\text {th }}$ edition, englewood Cliffs, New Jersey: Prentice-Hall International Inc.

Ikatan Akuntan Indoensia, 2001. Standar Akuntansi Keuangan. Jakarta: IAI.

Libby. Robert, Partricia A. Libby, and Daniel G. Short. 2007. Financial Accounting. Canada: Mc.Graw Hill Inc.

Manao (1997) dalam Task Force Komite Audit Forum Corporate Governance Indonesia, 30 Mei 2002.

Mintzberg, Hendry., Bruce Ahlstrand, and Joseph Lampel, 1998. Strategy safari: A Guided Tour Trough the Wilds of Strateic Management. New York: The Free Press.

Palepu, K.E., P.M. Healy, and V.B. Bernard., 2004. Business Analysis and Valuation. Cincinnati $\mathrm{OH}$ : South-Western.

Porter, Michael.E. 1992. Keunggulan bersaing: Menciptakan Keunggulan Bersaing. (terjemahan: Agus Dharma, Agus Maulana, E. Jasfi, dan Ujian Wahyu Suprapto). Jakarta:Erlangga.
Wallace, Peter and John Zinkin., 2005. Mastering Business in Asia: Corporate Governance. Singapure: John Wiley \& Son (Asia) Pte Ltd.

Ward, Keith., 1996. Strategic management accounting. British-Oxford: ButterworthHeinemann. 